\title{
Komunikasi Sistem Pembaca 2D Dengan Mesin Laser Marking Berbasis PLC
}

\author{
M. Syafei Gozali, S.T., M.T. ${ }^{1}$ and Marhasak Parsaoran ${ }^{2}$ \\ ${ }^{1,2}$ Politeknik Negeri Batam \\ Program Studi Teknik Mekatronika \\ *Email: ${ }^{\text {ssyafei@ } @ \text { polibatam.ac.id }}{ }^{2}$ mparsaoan@gmail.com
}

\begin{abstract}
Currently size of Integrated Circuits (IC) become smaller while it needs more information on its label. Therefore 2D data matrix is use to replace standard character for the identification. To improve laser mark machine capabilities to be able to read 2D data matrix, a $2 D$ reader system is required to integrate with existing laser mark machine. This study aims to develop 2D reader system that can read $2 D$ data matrix and communicates with laser mark machine automatically. Communication between 2D reader system and laser mark machine was done through Programmable Logic Control (PLC) inside the machine using serial (RS-232) by utilizes available data memories inside the PLC. The experimental result indicates the 2D reader system able to communicate with laser mark machine and it can differentiate readable and unreadable $2 \mathrm{D}$ data matrix. Unreadable 2D Code was caused by different process on the tested material. The readable 2D Code through Chemical Deflash - Water Jet (CD-WJ) process while the unreadable 2D Code run without CD-WJ.
\end{abstract}

Keyword: Data matrix, reader, PLC, serial.

\section{PENDAHULUAN}

Pada dunia industri perakitan Integrated Circuit (IC) terdapat beberapa proses yang digunakan dan salah satunya adalah proses Marking. Pada proses ini bagian penutup IC (compound / lid) diberi merk / nama menggunakan sinar laser sesuai dengan permintaan. Merk IC ini memiliki beberapa informasi mulai dari nama/logo, jenis dan tanggal pembuatan IC.

Selain informasi diatas, saat ini pelanggan mengharapkan adanya fungsi anti mixing untuk menghindari bercampurnya IC antara lot satu dengan lainnya dan bahkan untuk traceability. Setiap IC yang dirakit memiliki informasi yang dibuat sedemikian rupa sehinga jika terjadi kesalahan akan memudahkan untuk mencari penyebabnya.

Dengan banyaknya informasi yang ada pada IC dengan ukuran yang kecil tidak memungkinkan untuk menggunakan standar huruf ataupun angka. Sehingga diperlukan perubahan data kedalam bentuk 2D data matrix. Oleh karena itu untuk memenuhi persyaratan dan harapan pelanggan, perusahaan semikonduktor harus mengikuti perubahan. Dalam hal ini perlu adanya suatu sistem pembaca $2 \mathrm{D}$ data matrix yang dapat berkomunikasi atau berintegrasi dengan mesin Laser Mark yang sudah ada.

Pada penelitian akan dibuat komunikasi dari mesin Laser Mark yang menggunakan PLC dengan sistem pembaca 2D.

\section{TINJAUAN TEORI}

\section{A. Marking}

Marking adalah salah satu proses dalam industri perakitan IC yang bertujuan untuk memberikan merk atau nama berdasarkan permintaan pelanggan. Pemberian nama dilakukan pada bagian compound/lid menggunakan sinar laser.

Material yang akan diproses dimasukkan ke dalam magazine dan ditempatkan pada unloader, kemudian posisi/arah material akan di cek pada proses Pre Mark / Orientation Inspection sebelum masuk proses Laser Marking. Setelah proses laser, merk yang sudah dibuat akan dicek pada area Post Mark Inspection lalu diteruskan ke Unloader.

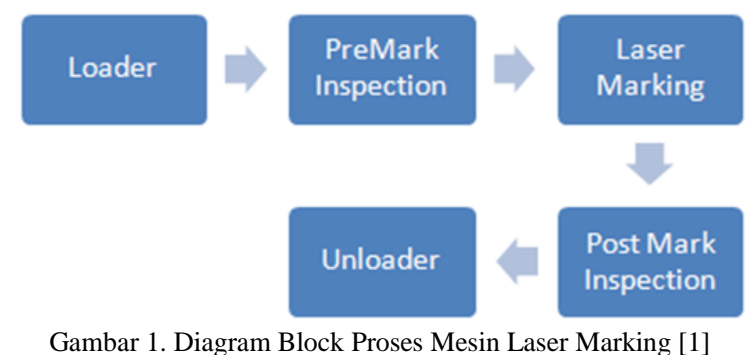

\section{B. Kamera $2 D$}

Kamera yang digunakan adalah merek KEYENCE SR1000. Kamera memiliki sistem pencahayaan sendiri dan pengaturan fokus secara otomatis. 


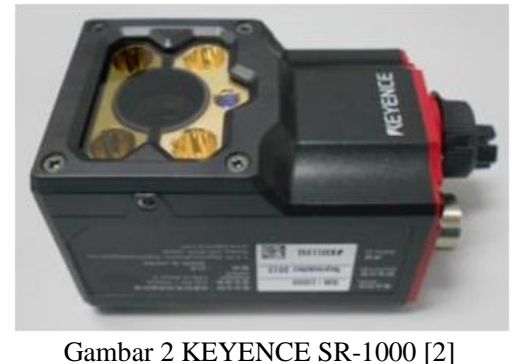

KEYENCE SR-1000 dapat membaca 2D Code dan Barcode. Kode yang berhasil dibaca akan diterjemahkan ke dalam bentuk numerik dan dikirim ke sistem laser yang kemudian digunakan sebagai data yang akan digunakan pada proses laser. Komunikasi bisa dilakukan menggunakan serial, USB dan Ethernet.

\section{Barcode}

Bar Code atau biasa ditulis Barcode adalah gambar berupa garis yang biasa terdapat pada sebuah produk yang digunakan untuk mewakili angka yang berisi informasi sebuah produk. Barcode terdiri dari 5 bagian yaitu quite zone, start character, data, check digit dan stop character seperti telihat pada Gambar 3. Format Barcode.

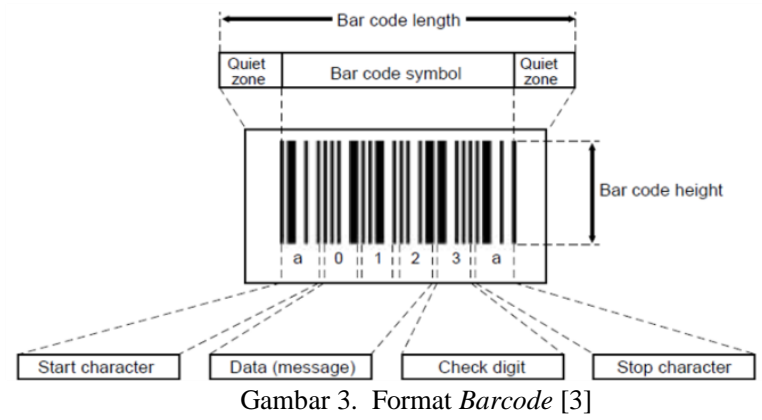

Barcode hanya bisa berisi 30 karakter, sehingga kode yang dapat memuat data yang lebih banyak dibuat dalam bentuk kode 2D. Kode 2D dapat berisi data hampir seratus (100) kali lebih banyak dan ukuran yang sepuluh (10) kali lebih kecil dibandingkan dengan barcode.

Terdapat 2 jenis kode 2D yaitu jenis stack dan matrix. Jenis stack terdiri dari barcode yang ditumpuk secara vertikal pada sebuah segi empat seperti terlihat pada Gambar 4. 2D Jenis Stack sedangkan jenis matrix disusun dari kotak-kotak atau titik-titik kecil yang berbentuk kotak seperti terlihat pada gambar 5. 2D Jenis Matrix.

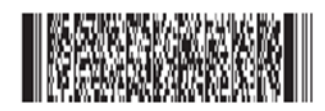

PDF417

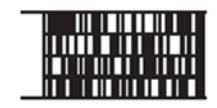

Code 49

Gambar 4. 2D Jenis Stack [4]

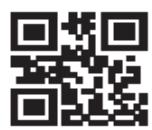

QR code

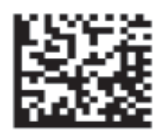

Data Matrix Gambar 5. 2D Jenis Matrix [4]

\section{Pemograman PLC.}

Terdapat beberapa cara atau desain yang digunakan untuk melakukan pemrograman pada PLC yaitu :

1) Boolean Logic Design

Pada perancangan menggunakan desain Boolean dapat membuat fungsi logic yang lebih sederhana.

2) Structured Logic Design

Perancangan ladder diagram dengan menentukan urutan kerjanya, biasanya menggunakan fungsi SET dan RESET.

3) Flow Chart Based Design

Disain pemograman dengan menggunakan Diagram Alir (flowchart) sangat ideal untuk suatu proses yang memiliki langkah-langkah (Step) yang berurutan. Step akan dieksekusi dalam urutan yang dapat berubah sebagai hasil dari beberapa keputusan. Blok yang digunakan dihubungkan dengan menggunakan arah panah untuk menunjukan urutan step. Setiap blok mempunyai arti sendiri, berikut beberapa blok yang digunakan dalam flowchart.

4) State Based Design

Pada perancangan dengan State Based yaitu dengan membuat suatu state (keadaan) dari suatu sistem, yang kemudian dihubungkan dengan state lainnya dengan menggunakan transisi.

\section{E. Komunikasi PLC.}

Komunikasi antara C200HX dan komputer untuk pemrograman ataupun sebagai User Interface menggunakan komunikasi serial RS-232.

Terdapat 2 jenis komunikasi RS232 yang bisa digunakan pada PLC OMRON C200HG:

1) Internal Host Link

Komunikasi antara PLC DB-9 dengan komputer menggunakan DB-9 memiliki konfigurasi seperti Gambar 6. Konfigurasi RS-232 DB-9 ke DB-9.

\begin{tabular}{|c|c|}
\hline Signal & $\begin{array}{c}\text { Pin } \\
\text { No. }\end{array}$ \\
\hline FG & 1 \\
\hline SD & 2 \\
\hline RD & 3 \\
\hline RS & 4 \\
\hline $\mathrm{CS}$ & 5 \\
\hline- & 6 \\
\hline- & 7 \\
\hline- & 8 \\
\hline SG & 9 \\
\hline
\end{tabular}

Gambar 6. Konfigurasi RS-232 DB-9 ke DB-9 [5]

2) External Host Link (Communication Board)

Komunikasi antara communication board dengan DB-25 dan komputer DB-9 memiliki konfigurasi seperti ditunjukkan Gambar 7. Konfigurasi RS-232 DB-25 ke DB9 . 


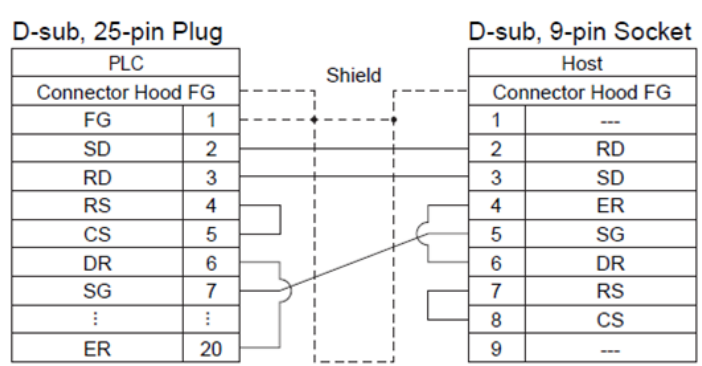

Gambar 7. Konfigurasi RS-232 DB-25 ke DB-9 [6]

\section{PERANCANGAN SISTEM}

\section{A. Rancangan Diagram}

Pada penelitian dilakukan pembuatan komunikasi antara mesin Laser Mark dan sistem pembaca 2D, seperti terlihat pada Gambar 8. Blok Diagram Sistem Otomasi.

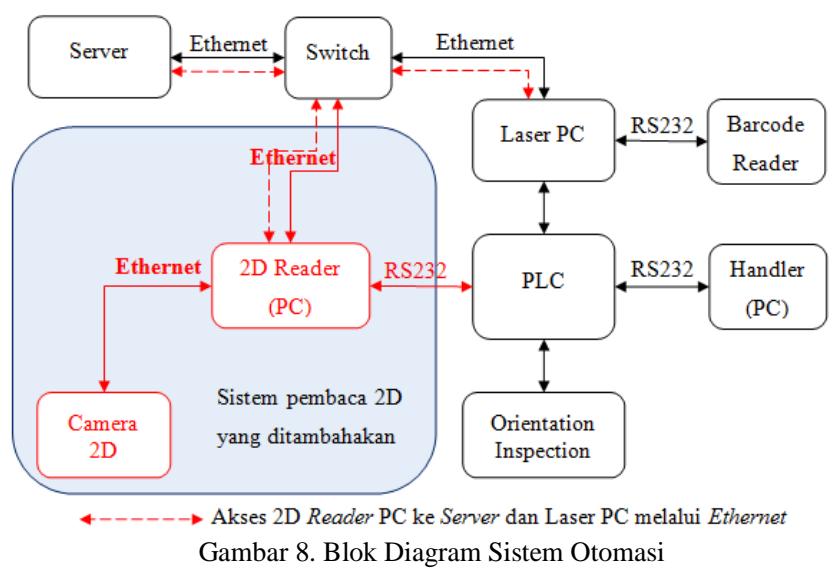

TABEL I

AKSES SERVER DAN LASER PC MELALUI ETHERNET

\begin{tabular}{|l|l|l|l|}
\hline Deskripsi & \multicolumn{2}{|c|}{ Diakses oleh } & \multicolumn{2}{c|}{ Keterangan } \\
\hline $\begin{array}{l}\text { Server } \\
\text { (SQL) }\end{array}$ & Laser & $\begin{array}{l}\text { 2D } \\
\text { Peader }\end{array}$ & $\begin{array}{l}\text { Membaca data } \\
\text { kolom SCT_Flag } \\
\text { pada SQL Server } \\
\text { untuk menentukan } \\
\text { fungsi 2D }\end{array}$ \\
\hline Laser PC & - & $\begin{array}{l}\text { 2D } \\
\text { Reader } \\
\text { PC }\end{array}$ & $\begin{array}{l}\text { Membaca data hasil } \\
\text { pembacaan Barcode } \\
\text { Reader dan } \\
\text { mengirim data hasil } \\
\text { pembacaan 2D. }\end{array}$ \\
\hline
\end{tabular}

Data pembacaan dari Barcode Reader pada komputer laser akan dibaca oleh sistem pembaca 2D (2D Reader). Kemudian sistem pembaca 2D akan membaca informasi yang berada di server yang sesuai dengan hasil pembacaan Barcode Reader. Jika data bernilai 1 maka sistem pembaca 2D akan mengirim sinyal ke PLC untuk mengaktifkan fungsi 2D pada PLC dan menonaktifkan fungsi Orientation Inspection. Sedangkan jika data bernilai 0 maka sistem pembaca 2D akan mengirimkan sinyal ke PLC untuk mengaktifkan fungsi Orientation Inspection dan memonaktifkan fungsi 2D.

Pada saat fungsi 2D aktif dan sistem pembaca 2D mendapat sinyal dari PLC untuk membaca, maka sistem pembaca 2D akan memberikan sinyal kepada kamera untuk melakukan pembacaan. Jika kamera dapat membaca 2D data matrix kemudian sistem akan mengirim data hasil pembacaan 2D ke komputer laser dan sinyal Good (G) ke PLC sedangkan jika kamera tidak dapat membaca 2D data matrix maka sistem hanya mengirim kan sinyal No Good (NG) ke PLC.

\section{B. Rancangan Perangkat Keras}

Peralatan yang digunakan pada penelitian adalah kamera 2D KEYENCE SR-1000 yang terhubung dengan komputer menggunakan kabel Ethernet dan PLC dengan komputer secara serial seperti terlihat pada Gambar 9. Desain Lokasi Kamera dan Komputer.

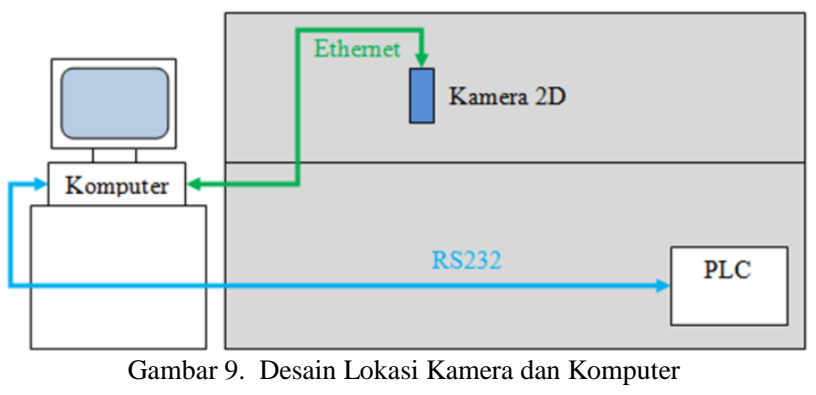

\section{Rancangan Perangkat Lunak.}

Terdapat dua perangkat lunak yang digunakan pada penelitian, yaitu:

1) Program $P L C$

Penelitian menggunakan ladder diagram akan dibuat berdasarkan Flowchart Based Design seperti Gambar 10. Flowchart Program PLC. Sistem pembaca 2D akan aktif jika kondisi material yang akan diproses memiliki informasi bahwa material menggunakan fungsi 2D Code.

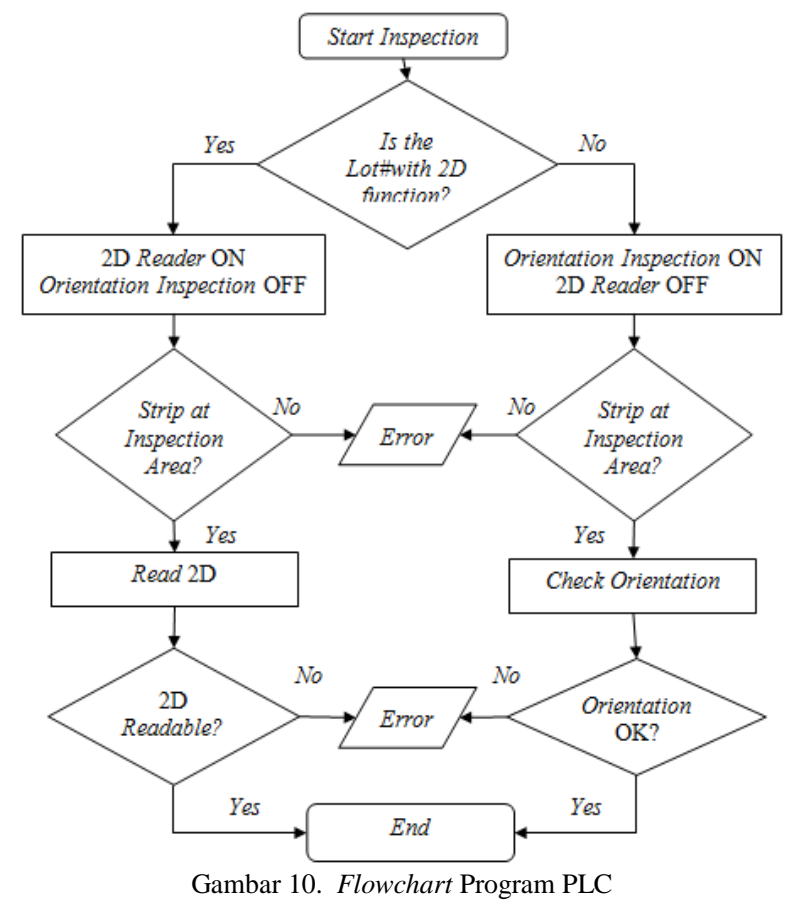


Pada saat terjadi error akan muncul message di PC handler, untuk membersihkan error dilakukan dengan menekan tombol Error Reset. Error yang disebabkan karena strip tidak ada di area orientasi dapat di-reset setelah penyebabnya diperbaiki sedangkan error yang terjadi karena hasil pembacaan No Good (NG), strip/material tersebut akan langsung di transfer ke Reject Bin tanpa ada proses pemberian merk oleh Laser.

2) Program C Sharp (C\#).

Program yang dibuat menggunakan $\mathrm{C \#}$ akan melakukan komunikasi antara Server, komputer Laser, kamera 2D dan PLC seperti Gambar 8 Blok Diagram Sistem Otomasi.

\section{HASIL DAN ANALISA}

\section{A. Hasil Pengujian Komunikasi Program C\# dan PLC.}

Komunikasi antara program C\# pembaca 2D dan PLC menggunakan komunikasi serial. Untuk memperoleh komunikasi yang baik dilakukan pengujian selama 60 detik untuk 4 nilai delay yang berbeda. Delay yang digunakan adalah $10 \mathrm{~ms}, 100 \mathrm{~ms}, 500 \mathrm{~ms}$ dan $1000 \mathrm{~ms}$. Data yang dikirim program C\# adalah @00RD0200001055*CR sedangkan yang diterima adalah@00RD000001000100000000000000000000 $00000000000056 * \mathrm{CR}$.

TABEL II COMMAND FORMAT

\begin{tabular}{|c|c|c|c|c|c|c|}
\hline \multicolumn{2}{|c|}{ Node No } & $\begin{array}{c}\text { Header } \\
\text { Code }\end{array}$ & Address & Address \# & FCS & Terminator \\
\hline$@$ & 00 & RD & 0200 & 0010 & 55 & $*$ CR \\
\hline
\end{tabular}

@00: No unit Hostlink

RD : Header code untuk membaca data memori PLC

0200: alamat data memori yang akan dibaca

0010: jumlah data memori yang akan dibaca mulai dari data memori 200

55: frame checksum untuk memeriksa data yang dikirim

*CR : batas akhir pengiriman data

TABEL III RESPONSE FORMAT

\begin{tabular}{|c|c|c|c|c|c|c|}
\hline \multicolumn{2}{|c|}{$\begin{array}{c}\text { Node } \\
\text { No }\end{array}$} & $\begin{array}{c}\text { Header } \\
\text { Code }\end{array}$ & $\begin{array}{c}\text { End } \\
\text { Codes }\end{array}$ & Read Data & FCS & Terminator \\
\hline @ & 00 & RD & 00 & $\begin{array}{l}0001000100000 \\
0000000000000 \\
00000000000000\end{array}$ & 56 & $*$ CR \\
\hline
\end{tabular}

@ 00: No unit Hostlink

RD : untuk membaca data memori PLC

00: indikator data yang dikirim tidak ada kesalahan 0001000100000000000000000000000000000000 : nilai data yang terdapat pada data memori mulai dari 200 sampai 209 55: frame checksum untuk memeriksa data yang dikirim

*CR : batas akhir pengiriman data
TABEL IV

DATA TRANSMIT / RECEIVE

\begin{tabular}{|c|c|c|c|}
\hline \multirow[t]{2}{*}{ Delay } & \multicolumn{2}{|c|}{ Jumlah Data } & \multirow[t]{2}{*}{ Sample data yang dikirim dan diterima } \\
\hline & Write & Read & \\
\hline 10 & 2910 & 478 & 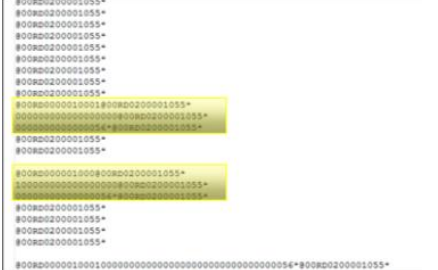 \\
\hline
\end{tabular}

Pada komunikasi serial menggunakan delay $10 \mathrm{~ms}$ terjadi overlap antara data yang dikirim dan yang diterima, sebelum data diterima aplikasi sudah mengirim data baru.

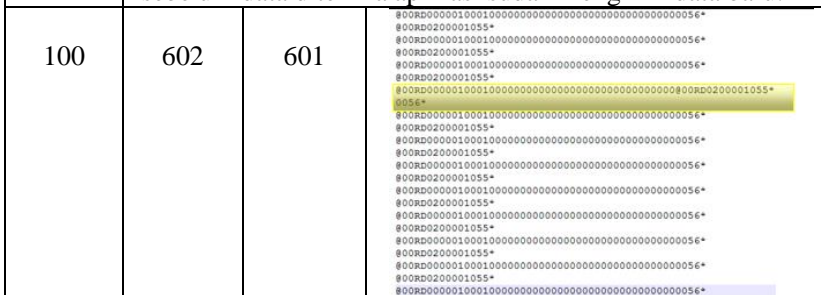

Pada komunikasi serial menggunakan delay $100 \mathrm{~ms}$ terjadi data kesalahan penerimaan data pada detik ke 58 , hanya sebagian data yang diterima dan menjadi satu dengan data yang baru.

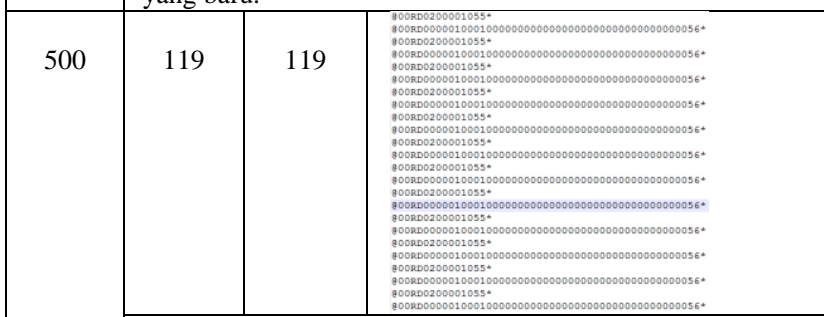

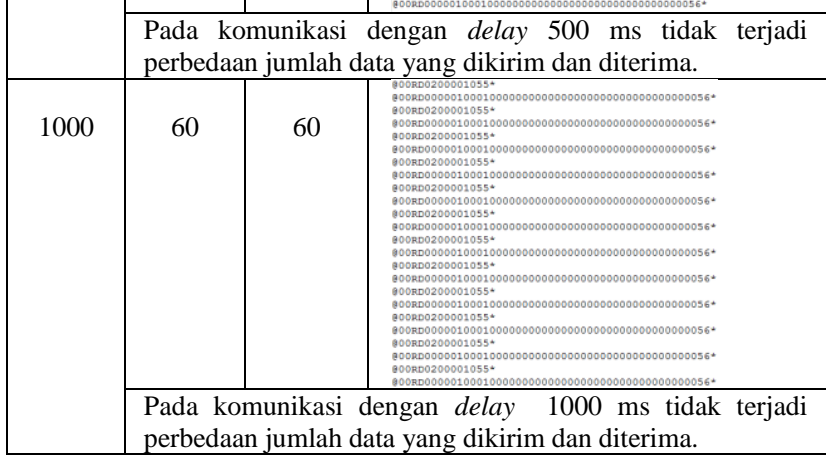

\section{B. Hasil Pengujian sistem pembaca $2 D$}

Pada saat program C\# aktif dan membaca nomor lot dengan data $\mathrm{SCT}=1$ maka fungsi pembaca $2 \mathrm{D}$ aktif dengan indikator ENABLE berwarna merah seperti Gambar 11. Fungsi Pembaca 2D Aktif sedangkan pada saat data SCT $=0$ maka fungsi pembaca 2D tidak aktif dengan indikator DISABLE berwarna merah seperti terlihat pada Gambar 12 . Fungsi Pembaca 2D Tidak Aktif.

Pada kondisi program C\# ENABLE dan menerima sinyal Start maka program akan membaca 2D dengan indikator START berwarna hijau seperti terlihat pada Gambar 13. Program C\# Menerima Sinyal Start.

Kondisi pada saat program C\# dapat membaca 2D data matrix dapat dilihat seperti Gambar 14. Program C\# Dapat Membaca 2D Data Matrix. Pada Reader terdapat kotak berwarna hijau di sekeliling gambar 2D data matrix, indikator 
Pass pada Data I/O akan berwarna merah dan pada log tedapat data numerik 2D data matrix hasil pembacaan.

Sedangkan kondisi pada saat program C\# tidak dapat membaca 2D data matrix dapat dilihat seperti Gambar 15. Program C\# Tidak Dapat Membaca 2D Data Matrix. Pada Reader tidak terdapat kotak berwarna hijau di sekeliling gambar 2D data matrix, indikator Fail pada Data I/O akan berwarna merah dan pada log tedapat kondisi error : "Unable read the barcode" dan "2D Reader Fail".
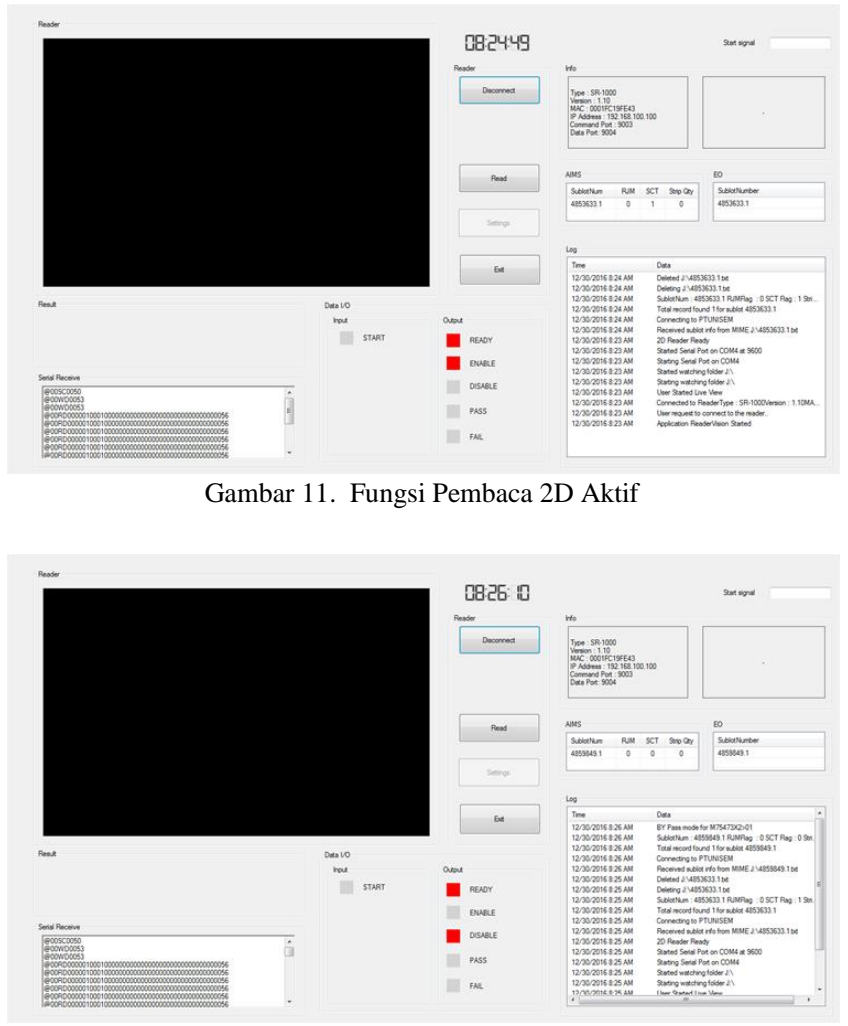

Gambar 12. Fungsi Pembaca 2D Tidak Aktif

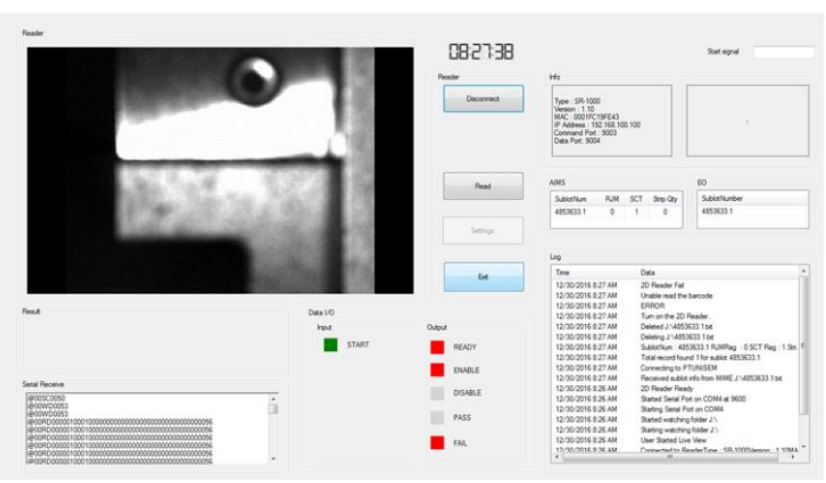

Gambar 13. Program C\# Menerima Sinyal Start

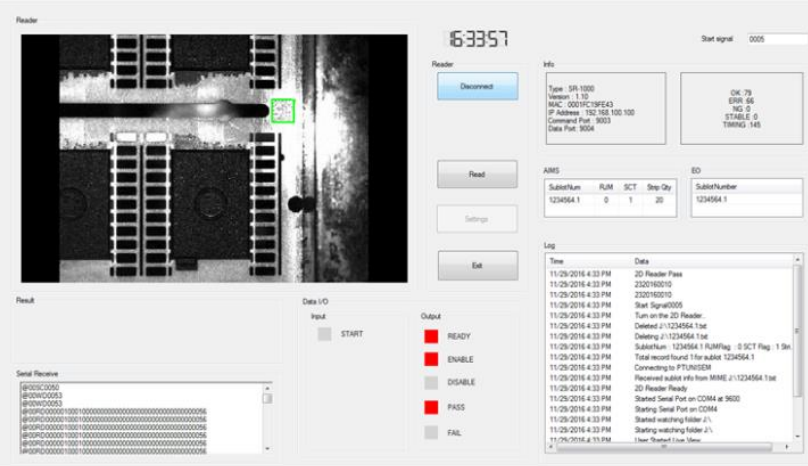

Gambar 14. Program C\# Dapat Membaca 2D Data Matrix

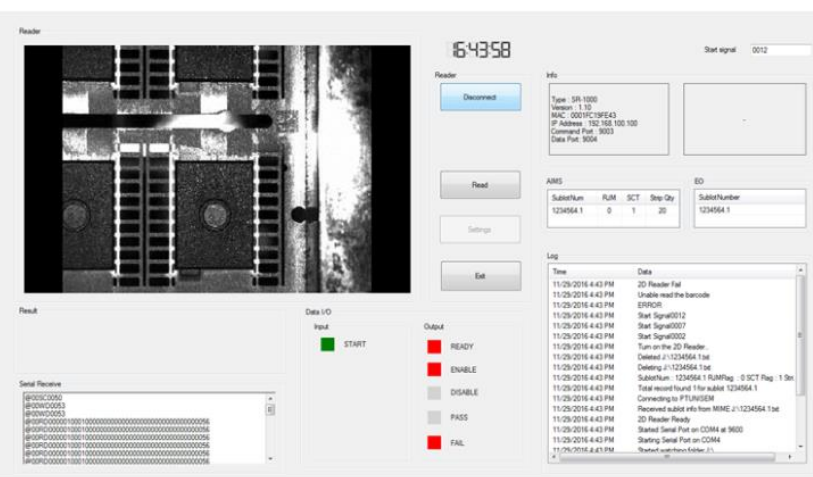

Gambar 15. Program C\# Tidak Dapat Membaca 2D Data Matrix

TABEL V

\begin{tabular}{|c|c|c|c|c|c|}
\hline \multicolumn{6}{|r|}{ Data 2D vang } \\
\hline & & & ada ap & & terbaca \\
\hline 1 & 22930020 & & & Terbaca & 2320160020 \\
\hline 2 & 22870014 & & & Terbaca & 2320160020 \\
\hline 3 & 22990026 & & & Terbaca & 2320160026 \\
\hline 4 & 22970024 & & & Terbaca & 2320160024 \\
\hline 5 & 22790006 & & & Terbaca & 2320160006 \\
\hline 6 & 22850012 & & & Terbaca & 2320160012 \\
\hline 7 & 22830010 & & & Terbaca & 2320160010 \\
\hline 8 & 22770004 & & & Terbaca & 2320160004 \\
\hline 9 & 10990048 & & & $\begin{array}{l}\text { Tidak } \\
\text { Terbaca }\end{array}$ & - \\
\hline 10 & 10910036 & & & $\begin{array}{l}\text { Tidak } \\
\text { Terbaca }\end{array}$ & - \\
\hline
\end{tabular}


TABEL VI

PERBANDINGAN WAKTU PEMBACAAN ORIENTASI DAN 2D DATA MATRIX

\begin{tabular}{|c|c|c|}
\hline No & $\begin{array}{c}\text { Pembaca Orientasi } \\
(\mathrm{ms})\end{array}$ & $\begin{array}{c}\text { Pembaca 2D } \\
(\mathrm{ms})\end{array}$ \\
\hline 1 & 136 & 49 \\
\hline 2 & 167 & 51 \\
\hline 3 & 152 & 50 \\
\hline 4 & 136 & 50 \\
\hline 5 & 152 & 50 \\
\hline 6 & 167 & 51 \\
\hline 7 & 167 & 51 \\
\hline 8 & 167 & 50 \\
\hline 9 & 167 & 52 \\
\hline 10 & 151 & 51 \\
\hline
\end{tabular}

\section{ANALISA}

Komunikasi PLC dengan CPU yang hanya memiliki 1 port serial RS-232 seperti OMRON C-200HX dapat dilakukan dengan lebih dari satu komputer / program. Tambahan komunikasi serial dapat dilakukan dengan menggunakan tambahan hostlink yang dipasang pada back plane. Hardware yang digunakan adalah modul komunikasi C200H-LK201V1. Berdasarkan data dari Tabel. IV, delay $10 \mathrm{~ms}$ dan $100 \mathrm{~ms}$ memiliki jumlah data yang berbeda antara transmit dan receive. Sedangkan dengan menggunakan delay $500 \mathrm{~ms}$ dan $1000 \mathrm{~ms}$, memiliki jumlah data yang sama antara transmit dan receive.

Program C\# yang dibuat dapat membedakan 2D data matrix yang bisa terbaca ataupun tidak, kondisi ini dapat dilihat seperti Gambar 14. Kondisi Program C\# Dapat Membaca 2D Data Matrix dan Gambar 15. Kondisi Program C\# Tidak Dapat Membaca 2D Data Matrix.

Hasil percobaan aplikasi dapat dilihat pada TABEL V. Dari data ini dapat dilihat bahwa terdapat kondisi dimana sistem tidak dapat membaca 2D data matrix. Kondisi ini dikarenakan perbedaan proses di End Of Line (EOL) pada dummy yang digunakan. Dummy yang terbaca melewati proses Chemical Deflash - Water Jet (CD-WJ) setelah proses Molding dan Post Mold Cure (PMC), sedangkan dummy yang tidak terbaca tidak melalui proses $\mathrm{CD}-\mathrm{WJ}$.

Pembacaan 2D data matrix memiliki waktu yang lebih cepat dibandingkan dengan waktu pembacaan orientasi. Kondisi ini dapat dilihat pada TABEL VI. Berdasarkan data tersebut penambahan sistem pembaca 2D data matrix tidak mempengaruhi waktu proses pada mesin laser mark.

\section{KESIMPULAN}

Kesimpulan yang dapat diambil adalah:

1) Komunikasi antara sistem pembaca $2 \mathrm{D}$ data matrix dan PLC menggunakan komunikasi serial dengan delay $500 \mathrm{~ms}$.

2) Aplikasi akan mulai melakukan pembacaan 2D data matrix setelah mendapat sinyal dari mesin laser dan akan mengirimkan hasilnya ke mesin dengan menggunakan data memory yang terdapat pada PLC.

3) Penambahan sistem pembaca $2 \mathrm{D}$ data matrix tidak menambah waktu proses karena memiliki waktu pembacaan yang lebih cepat daripada sistem orientasi.

\section{REFERENSI}

[1] LS-300DE Strip Laser Marker System ETS-A0945, Rev.000, Ever Technologies Pte., Ltd., Singapore.

[2] Autofocus Code Reader SR-1000 Series, Rev 5.0, KEYENCE

[3] ID Code Hand Book - Bar Code Type Selection Guide, Vol.1, KEYENCE

[4] ID Code Handbook - 2-D Code Basic Guide, KEYENCE

[5] C200HX/C200HG/C200HE Programmable Controller Operation Manual, Revised August 2004, OMRON.

[6] SYSMAC WAY Host Link Units For Use With C-Series Rack PCs, Revised April 2001, OMRON. 